\title{
Minimum Ventilation Systems and their Effects on the Initial Stage of Turkey Production
}

\section{-Author(s)}

Mendes AS 1

Moura DJ2

Nääs $\mid A^{2}$

Morello $\mathrm{GM}^{3}$

Carvalho TMR 2

Refatti $R^{4}$

Paixão $S J^{4}$

Department of Agronomy. Federa Technological University of Paraná, Dois Vizinhos, PR, Brazil.

2 Department of Environmental Controls and Rural Constructions. State University of Campinas (UNICAMP), Campinas, SP, Brazil.

3 Graduate Research Assistant at the Animal Sciences Department, Purdue University, West Lafayette, IN, 47906, U.S.A.

4 Animal Science Department, Federal Tecnhological University of Paraná (UTFPR), Dois Vizinhos, Paraná, Brazil.

\section{-Mail Adress}

Corresponding author e-mail address angelica@utfpr.edu.br

\section{"Keywords}

Air renewal, gases, poultry house, thermal comfort.

\section{ABSTRACT}

This study aimed at evaluating the live performance of turkeys during the initial stage of production (1-26 days of age) and to map the environmental variables inside turkey houses, such as temperature, relative humidity, $\mathrm{CO}_{2}$ concentration, at two distinct minimum ventilation systems. House $1(\mathrm{H} 1)$ was equipped with a negative-pressure ventilation system and House $2(\mathrm{H} 2)$ was equipped with a positivepressure ventilation system. This study was performed in commercial poultry houses, located in Francisco Beltrão, Paraná, Brazil, in June, 2008. A number of 14,000 turkeys toms at the same age, provided by the same local hatchery and were housed at a stocking density of 23 birds $\mathrm{m}^{-2}$. Three $13 \mathrm{~m}^{2}$ boxes with 300 turkeys each were placed inside the poultry houses. All treatments were assigned for the birds inside each of the three boxes. The poultry barns were virtually divided in eight equally distributed in areas where the environmental variables were recorded. The performance parameters measured were weight gain, feed conversion and mortality rate, recorded weekly. Analysis of variance and F-tests were performed to compare results within different environmental conditions, using MINITAB 14 statistical software. The ventilation systems did not significantly influence $\mathrm{CO}_{2}$ concentrations $(p=0.489)$, whereas temperature $(p=0.016)$ and relative humidity ( $p$ $=0.0001)$ and feed conversion $(p=0.001)$ were significantly affected by ventilation system. Temperature and relative humidity in $\mathrm{H} 2$ (positive pressure ventilation system) was found to be less aversive than those in $\mathrm{H} 1$ (negative pressure system). Also, bids in $\mathrm{H} 2$ presented lower feed conversions than those in $\mathrm{H} 1$.

\section{INTRODUCTION}

During recent decades, fast-growing meat-type turkeys have shown significant improvements in growth performance, feed conversion and livability (Havenstein et al., 2007), mainly as a result of progressive genetic selection. However, together with this improvement, there was a significant increase in heat production, with consequent problems in coping with extreme environmental conditions. For many years, research has mainly focused on the effects of environmental temperature and, to a lesser extent, of relative humidity (Yahav et al., 1998) on the performance and thermoregulation of young and mature turkeys.

Good air quality in poultry houses requires cooling and/or heating systems capable of providing a balanced environment in terms of temperature and relative humidity. According to Senthilselvan et al. (1997), the incidence of respiratory disorders in humans that work in swine barns is a consequence of an unbalanced environment. Relative humidity and temperature may impact air quality by influencing the proliferation and survival of some pathogens, which may cause disease, 
animal welfare proble$\mathrm{ms}$ and performance impairment (Yalçin et al., 1997; Wathes et al., 1998).

Only recently there has been a shift of interest on the effects of ventilation rate (VR) on the thermoregulation and performance of turkeys. Yahav et al. (2009) studied the effects of different ventilation rates (VR) on the performance and thermoregulation

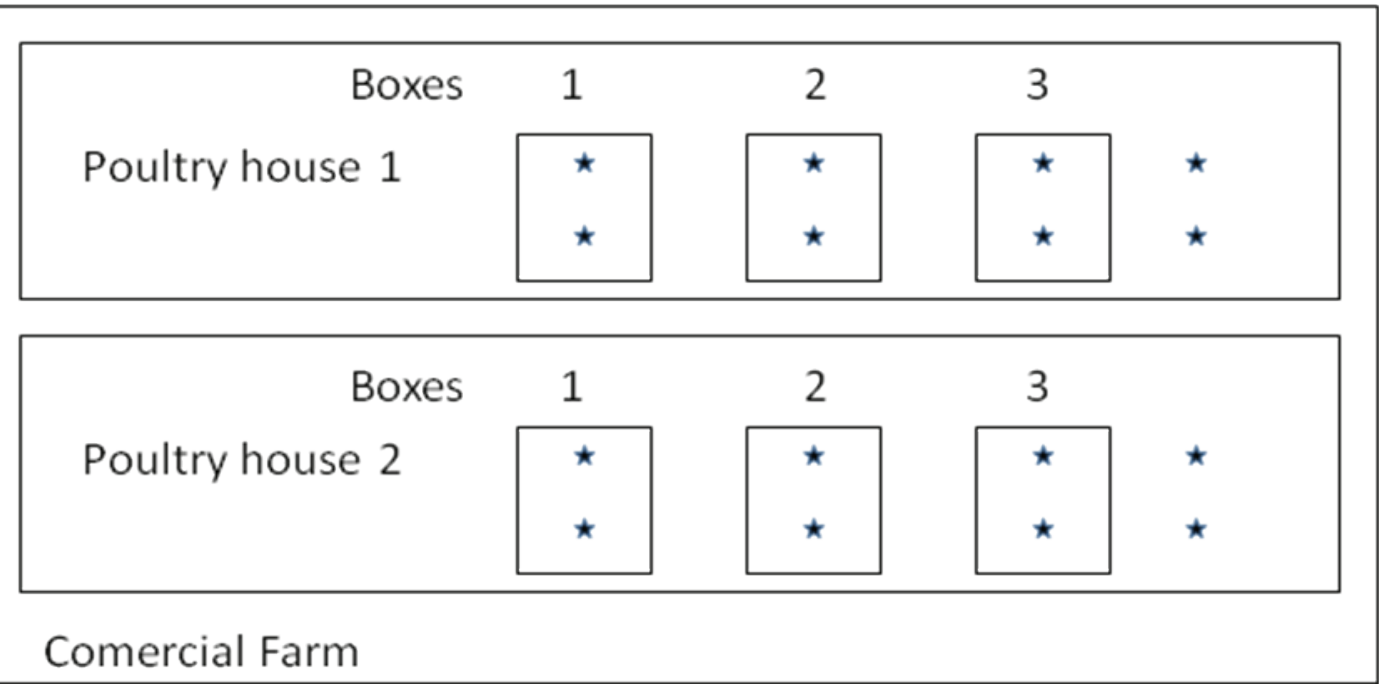

Figure 1 - Scheme of the top view of poultry houses 1 and 2, boxes and data logger positions. of young turkeys exposed to constant environmental temperatures, and found that VR significantly affected live performance. The first few weeks post-hatch are crucial for subsequent growth and development of turkeys (Yahav et al., 2011). Therefore, more studies are needed to help understanding how environmental factors affect the performance of domestic fowls, including turkeys.

Monitoring environmental variables, such as environmental temperature, relative humidity and gas concentrations, is essential for effectively controlling the physical environment inside barns where animals are reared. Animal heat and moisture production rates provide substantial information for the design and operation of mechanical ventilation systems (Gates et al., 2005). Although there is limited literature available on heat and moisture production by turkeys, it is known that environmental variables inside poultry houses can be controlled by air exchange, which depends on the type of ventilation system used, as well as on its operation schedule (Goovaerts, 1997).

According Yahav et al. (2011), the VR range (expressed as air velocity, AV) that allowed optimal body weight gain widened as environmental temperature declined from 35 to $25^{\circ} \mathrm{C}$, and the authors concluded that $30^{\circ} \mathrm{C}$, combined with AV between 1.5 and $2.5 \mathrm{~ms}^{-1}$, provided the optimal conditions for young turkeys.

Both brooding and finishing phases in turkey production require adequate ventilation systems in order to provide the fresh air required to maintain a good air quality, as well as to promote efficient operation of the cooling and heating systems. The ventilation system is one of the main factors that contribute for the establishment of an adequate environment inside poultry houses (Barber et al.,
1991; Wang et al., 1999). Minimum ventilation can be provided both by positive and negative pressure systems, when the air is blown into the house or exhausted from the house, respectively. Both negative and positive pressure systems allow the removal of heat and excessive moisture, reduce dust and odors, controlling the build-up of harmful gases, such as ammonia and carbon dioxide, as well as supply oxygen for respiration (Bucklin et al., 2009).

Therefore, studying the efficacy of ventilation systems is essential to improve productivity and promote good animal welfare. This study aimed at evaluating two types of ventilation systems and their effects on the environment inside turkey houses and on turkey performance during the brooding phase.

\section{MATERIAL AND METHODS}

\section{Birds and husbandry}

A total of 900 turkey toms obtained from the same hatchery were randomly distributed into three $13-\mathrm{m}^{2}$ pens with 300 birds each, placed in two commercial turkey houses that housed 14,000 one-day-old Nicholas turkey toms at a stocking density of 23 birds $\mathrm{m}^{-2}$. The 900 experimental birds were housed at one day of age, and were reared until 26 days old. Birds had access to water and feed ad libtum three times a day: 7:00h, 12:00h and 17:00h.

This study was carried out in two $50.0 \times 12.0 \times 2.7$ $\mathrm{m}$ identical commercial turkey houses, located in one farm in Francisco Beltrão, PR, Brazil. Turkey house 1 (NP) was equipped with a negative-pressure ventilation system, whereas turkey house 2 (PP) was equipped with a positive-pressure ventilation system. 
Two $120 \mathrm{~m}^{3}$ min-1 fans were installed at the ceiling of each poultry house. The brooding system consisted of three wood furnaces inside each house. Figure 1 illustrates the location of the $13-\mathrm{m}^{2}$ pens (replicates) inside Turkey Houses 1 and 2, as well as the position of the data loggers.

All the fans inside the barns were programmed to operate identically, moving air at a rate of approximately $0.9 \mathrm{~m}^{3} \mathrm{~s}^{-1}$ per 10,000 birds each, as recommended by Nixey \& Grey (1989) for $0.5 \mathrm{~kg}$ birds during the brooding phase. Table 1 shows the operation of fans inside the houses during the four experimental weeks.

Table 1 - Minimum ventilation operation program.

\begin{tabular}{cccccc}
\hline Weeks & $\begin{array}{c}\text { Bird } \\
\text { weight } \\
(\mathrm{kg})\end{array}$ & $\begin{array}{c}\text { Air flow } \\
\text { rate* } \\
\left(\mathrm{m}^{3} / \mathrm{s}\right)\end{array}$ & $\begin{array}{c}\text { Air flow } \\
\text { rates* } \\
\left(\mathrm{m}^{3} / \mathrm{s}\right)\end{array}$ & $\begin{array}{c}\text { Number } \\
\text { of fans }\end{array}$ & Turned ON/OFF \\
\hline 1 & 0.14 & 0.3528 & 21.168 & 2 & 30 s ON/297s OFF \\
\hline 2 & 0.33 & 0.8316 & 49.896 & 2 & 30s ON/114s OFF \\
\hline 3 and 4 & 0.6 & 1.5112 & 90.672 & 2 & 60s ON/100s OFF \\
\hline
\end{tabular}

${ }^{*}$ Circulated air for 14.000 birds.

Table 2 - Carbon dioxide concentration $\left(\mathrm{CO}_{2}, \mathrm{ppm}\right)$, temperature $\left(\mathrm{T},{ }^{\circ} \mathrm{C}\right)$ and relative humidity $(\mathrm{RH}, \%)$, collected at 8:00h, 12:00h and 17:00h, averaged per data collection date (June 7 - 26), according to ventilation system.

\begin{tabular}{|c|c|c|c|c|c|c|}
\hline \multirow{2}{*}{$\begin{array}{l}\text { Ventilation } \\
\text { system }\end{array}$} & \multirow[b]{2}{*}{$\begin{array}{l}\text { Recording } \\
\text { time }\end{array}$} & \multirow[b]{2}{*}{ Variables } & \multicolumn{4}{|c|}{ Date } \\
\hline & & & Jun 7 & Jun 14 & Jun $15-21$ & Jun 22- 26 \\
\hline \multirow{9}{*}{ NP } & \multirow{3}{*}{ 8:00h } & $\mathrm{CO} 2$ & $1833.5 \pm 2.33$ & $2918.3 \pm 3.13$ & $2939.1 \pm 3.08$ & $3663.4 \pm 2.90$ \\
\hline & & $\mathrm{T}$ & $22.6 \pm 0.95$ & $27.5 \pm 0.99$ & $27.4 \pm 0.89$ & $28.4 \pm 1.01$ \\
\hline & & $\mathrm{RH}$ & $63.3 \pm 1.12$ & $74.4 \pm 1.09$ & $75.5 \pm 1.22$ & $75.1 \pm 1.32$ \\
\hline & \multirow{3}{*}{$12: 00 h$} & $\mathrm{CO}_{2}$ & $1520.1 \pm 2.85$ & $1730.2 \pm 2.33$ & $2473.8 \pm 2.03$ & $1557.4 \pm 2.42$ \\
\hline & & $\mathrm{T}$ & $29.2 \pm 0.88$ & $29.2 \pm 0.91$ & $27.6 \pm 1.00$ & $26.5 \pm 0.99$ \\
\hline & & $\mathrm{RH}$ & $51.2 \pm 1.12$ & $61.7 \pm 1.54$ & $66.5 \pm 1.22$ & $65.9 \pm 1.22$ \\
\hline & \multirow{3}{*}{ 17:00h } & $\mathrm{CO}_{2}$ & $1704.9 \pm 2.39$ & $2272 \pm 2.55$ & $3233.5 \pm 2.89$ & $2257.3 \pm 2.76$ \\
\hline & & $\mathrm{T}$ & $29 \pm 1.33$ & $29.1 \pm 0.33$ & $27.5 \pm 0.93$ & $25.6 \pm 1.03$ \\
\hline & & $\mathrm{RH}$ & $51.1 \pm 1.13$ & $67.3 \pm 0.83$ & $72.9 \pm 1.33$ & $66 \pm 1.33$ \\
\hline \multirow{9}{*}{ PP } & \multirow{3}{*}{$8: 00 h$} & $\mathrm{CO}_{2}$ & $1747.7 \pm 1.88$ & $3228.2 \pm 2.33$ & $2925.1 \pm 2.77$ & $3751.4 \pm 3.03$ \\
\hline & & $\mathrm{T}$ & $23.5 \pm 0.76$ & $27.2 \pm 0.93$ & $28.3 \pm 1.00$ & $28.6 \pm 1.11$ \\
\hline & & $\mathrm{RH}$ & $54.9 \pm 1.33$ & $71.7 \pm 1.78$ & $70.7 \pm 1.87$ & $68.6 \pm 1.39$ \\
\hline & \multirow{3}{*}{$12: 00 h$} & $\mathrm{CO}_{2}$ & $1406.4 \pm 2.03$ & $1717.2 \pm 2.10$ & $2185.9 \pm 1.99$ & $1900.4 \pm 2.00$ \\
\hline & & $\mathrm{T}$ & $29.9 \pm 0.66$ & $30.7 \pm 1.33$ & $28.2 \pm 1.22$ & $27.1 \pm 1.42$ \\
\hline & & $\mathrm{RH}$ & $47.2 \pm 1.93$ & $59.4 \pm 2.02$ & $61.2 \pm 2.00$ & $62.8 \pm 2.00$ \\
\hline & \multirow{3}{*}{$17: 00 h$} & $\mathrm{CO}_{2}$ & $1827.1 \pm 2.83$ & $2609.8 \pm 3.33$ & $3142.8 \pm 3.09$ & $2466.4 \pm 2.44$ \\
\hline & & $\mathrm{T}$ & $29.4 \pm 0.77$ & $30.1 \pm 1.33$ & $28.8 \pm 1.44$ & $26 \pm 1.19$ \\
\hline & & $\mathrm{RH}$ & $48.8 \pm 1.80$ & $61.9 \pm 2.00$ & $68.8 \pm 2.09$ & $62 \pm 2.33$ \\
\hline
\end{tabular}


in each pen. The feed remaining in the feeders after the birds were allowed to eat was weighed in order to determine feed intake in order to calculate feed conversion ratio. Feed and body weight were measured using a digital scale.

A completely randomized experimental design with three replicates (pens) per treatment (ventilation system) was applied. Environmental data were submitted to analysis of variance and the F-test was performed to compare means at $95 \%$ confidence level, using the statistical software Minitab, version 14.0 (Ryan et al., 1985).

\section{RESULTS AND DISCUSSION}

Table 2 shows the environmental data collected during 26 experimental days in both poultry houses $(\mathrm{H} 1$ and $\mathrm{H} 2)$, whereas Table 3 shows the results of the analysis of variance of the environmental data. As shown in Table 3, ventilation systems did not significantly influence $\mathrm{CO}_{2}$ concentrations. However, ventilation system affected temperature and relative humidity inside the turkey houses. Also, bird age (designated by date of data collection) and time of data collection significantly influenced all variables evaluated.

The results shown in Table 3 agree with those reported by Xin et al. (1998), who found that environmental temperature and relative humidity may vary according to the ventilation system used in male turkey houses. Seo et al. (2006) found that maintaining adequate and uniform environments inside large broiler houses may be difficult. According to Andonov et al. (2003) and to Mutaf et al. (2004), ventilation efficacy is related to the design of the ventilation system, which was observed in experiments with pigs. Wang \& Zhang (1999) also reported that environmental temperature and air velocity are related to the type of ventilation system adopted. Moreover, ventilation efficacy is primarily affected by the type of ventilation system applied, followed by the effects of the fan operation program (Zhang et al., 2001).

Klooster et al. (1993) compared positive-pressure with negative-pressure ventilation systems and concluded that the exhausting (negative-pressure) ventilation system was $40 \%$ more efficient in terms of environmental dust removal than the positive-pressure ventilation system. Wang (2000) observed that the average dust removal rate increased $196 \%$ when air outlets were correctly positioned.

Carbon dioxide concentrations were significantly influenced by bird age and recording time (Table 3). The lowest $\mathrm{CO}_{2}$ concentrations were obtained at 12:00h, which was the time of the day when the curtains were most frequently opened and therefore, air was usually renewed. During the initial phase of the experiment, $\mathrm{CO}_{2}$ concentrations were lower, as young birds produce less manure and present lower respiration rates than older birds. This result is consistent with the findings of Xin et al. (1998), who studied heat and moisture production in Nicholas turkeys during the five-week brooding-growing period and also found strong correlation between $\mathrm{CO}_{2}$ concentrations both with bird age and body mass. Since turkeys are sensitive to high $\mathrm{CO}_{2}$ and ammonia concentrations, ventilation systems must be well designed and effective; otherwise, young turkeys may become drowsy, reduce their water and feed intake, and therefore may present higher mortality rates (Boni et al., 2007).

Independently of treatment, average $\mathrm{CO}_{2}$ concentrations were within the recommended limits of 3,000 ppm (Noll et al., 2003) and 2,500 ppm (Frame et al., 1999) for turkey production. According to Gerritzen et al. (2006), turkeys can sense $\mathrm{CO}_{2}$ at concentrations

Table 3 - Analysis of variance of the environmental variables: $\mathrm{CO}_{2}$ concentration (ppm), temperature $\left(\mathrm{T},{ }^{\circ} \mathrm{C}\right)$ and relative humidity $(\mathrm{RH}, \%)$.

\begin{tabular}{llllllllll}
\hline & \multicolumn{2}{l}{$\begin{array}{l}\mathrm{CO}_{2} \text { concentration } \\
\text { (ppm) }\end{array}$} & & \multicolumn{3}{l}{$\begin{array}{l}\text { Temperature } \\
\left({ }^{\circ} \mathrm{C}\right)\end{array}$} & & & \multicolumn{3}{l}{$\begin{array}{l}\text { Relative humidity } \\
(\%)\end{array}$} \\
\hline Component & DF & $\mathrm{F}$ & $\mathrm{p}$ & $\mathrm{DF}$ & $\mathrm{F}$ & $\mathrm{p}$ & $\mathrm{DF}$ & $\mathrm{F}$ & $\mathrm{p}$ \\
Ventilation system & 1 & 0.48 & 0.489 & 1 & 5.8 & 0.016 & 1 & 35.22 & 0.000 \\
Age & 2 & 87.43 & 0.000 & 2 & 5.75 & 0.003 & 2 & 188.43 & 0.000 \\
Hour & 2 & 68.53 & 0.000 & 2 & 29.2 & 0.000 & 2 & 68.34 & 0.000 \\
$\mathrm{CV}(\%)$ & 13.1 & & & 5.2 & & & 7.1 & & \\
\hline
\end{tabular}

$\mathrm{DF}=$ Degrees of freedom; $F=F$-value; $\mathrm{p}=\mathrm{p}$-value; $\mathrm{CV}=$ Coefficient of Variance. 
of $2.3 \%$ and may suffer seizures at concentrations of $26 \%$, which demonstrates the importance of adequate operation of minimum ventilation. However, Seedorf et al. (1998) states that the ventilation rates commonly used in animal housing may not be sufficient for maintaining adequate air quality, depending on litter management practices.

Environmental temperature was lowest at 8:00h in both treatments when birds were between one and 14 days of age. This indicates that the brooding system was not capable of supplying sufficient heat to cover the low heat generation of young birds when the external temperatures were lowest $(8: 00 \mathrm{~h})$. On the other hand, during the last experimental days, the highest temperatures were measured at 8:00h due to the higher heat production by the birds, and because side curtains were usually closed at this time of the day. This change in temperature inside poultry houses was also observed by Miragliotta (2005), who studied different broiler stocking densities and different ventilation systems inside broiler houses. The author found major differences between environmental temperature and relative humidity during the distinct heating phases in the barns.

In the current study, temperature was $25^{\circ} \mathrm{C}$ or higher for most part of the time (Table 3). Temperatures below $25^{\circ} \mathrm{C}$ are considered adverse for young turkeys, as suggested by Yahav et al. (2009), who found young turkeys housed below $25^{\circ} \mathrm{C}$ directed a significantly higher proportion of energy for body temperature maintenance, i.e., they felt cold, irrespective of air velocity.

The positive-pressure house presented the highest environmental temperatures, independently of age or time of data collection (Table 2). This result suggests that the positive pressure ventilation system allowed for a greater mixing of the outside air with the heated air, which tends to stay close to the ceiling. This effective air mixing may have reduced heat loss, contributing to maintain environmental temperatures higher levels inside the PP house. On the other hand, negative pressure ventilation systems initially exhaust the previously heated air inside the barn, which may have contributed to lower temperatures levels in the NP house, which was equipped with a negative pressure ventilation system.

The environmental temperatures inside both houses (NP and PP) were not maintained within the optimal temperature range recommended in the guidelines by Nicholas Turkeys, Lewisburg, WV, USA. Still, the measured temperatures were within the turkeys' thermalneutral zone: first week (25 to 32 $\left.{ }^{\circ} \mathrm{C}\right)$; second week (24 to $31^{\circ} \mathrm{C}$ ); third week (23 to 30 ${ }^{\circ} \mathrm{C}$ ) and fourth week (22 to $29^{\circ} \mathrm{C}$ ). Menegali et al. (2008) found that both positive and negative pressure ventilation systems provided adequate environmental conditions for turkey production in Brazil, because the environmental temperatures inside the barns did not exceed the upper critical temperature of the turkeys' thermal comfort, which could impair bird performance (Van der Hel et al., 1992).

The highest relative humidity levels were obtained at 8:00h, independently of age, because curtain opening was less frequent and external environmental temperatures were lower at this time of measurement. Also, humidity rates increased during the last two experimental weeks, as older turkeys produce more moisture and require less heating. Accordingly, Yahav et al. (1998) reported that 10 to 19-week-old turkeys can cope better with relative humidity challenges than younger turkeys, which emphasizes the need of a better control of moisture level for younger birds, avoiding humidity fluctuations during rearing.

Miragliotta (2005) observed higher moisture levels at lower temperature spots inside poultry barns and attributed this finding to the lower capacity of the air to hold moisture when temperatures are low. Average environmental conditions are usually within $50 \%$ to $70 \%$ the thermal comfort range of the birds (Miragliotta, 2005; Menegali et al., 2008). However, in the present study, relative humidity levels exceeded the upper limit of turkeys' thermal comfort zone during the mornings of the last experimental days in both treatments (NP and PP). Because PP presented the highest temperatures, it also had the lowest relative humidity levels.

Table 4 shows the effects of treatments on average body weight, feed conversion ratio and mortality rates. Birds submitted to treatment NP were heavier and presented worse feed conversion and lower mortality rate compared with those submitted to treatment PP.

Table 4 - Analysis of variance of performance parameters.

\begin{tabular}{llll}
\hline Variable & Final weight $(\mathrm{g})$ & $\begin{array}{l}\text { Feed conversion } \\
(\mathrm{g} / \mathrm{g})\end{array}$ & $\begin{array}{l}\text { Mortality } \\
(\%)\end{array}$ \\
\hline Poultry House 1 & $804^{\mathrm{ns}}$ & $1335^{*}$ & $2.64^{\mathrm{ns}}$ \\
Poultry House 2 & 759 & 1297 & 4.58 \\
CV & 1.28 & 7.6 & 0.28 \\
\hline
\end{tabular}

* Significant at $95 \%$ confidence level by the F-test.

ns: not significant at $95 \%$ confidence level 
These results agree particularly with those obtained by Menegall et al. (2008), who performed a similar study with broiler chickens and determined worse feed conversion and lower mortality rate when birds were reared in housed equipped with negative-pressure ventilation systems. Seo et al. (2006) also reported that ventilation system may impact the environment of animal houses. On the other hand, Feedes et al. (2003) did not find any influence of ventilation rate or air velocity on broiler mortality, as well as Weaver \& Meijerhof (1991) did not find any effect of ventilation on mortality rate.

Zuidhof et al. (1993) found higher incidence of respiratory disorders in turkeys and lower $\mathrm{O}_{2}$ concentrations inside barns with reduced air change rates. Feed conversion and weight gain were also better when brids were reared in houses with higher air exchange rates. As previously reported, the rate of air change has more impact on turkey performance than turkey stocking density (Janni et al., 1989; Feedes et al., 2003).

According Yahav et al. (2011), under diurnallycycling conditions, it must be considered that using appropriate ventilation rates may partially offset the negative effects of environmental temperature. Also, Cordeau \& Barrington (2010) stated that air temperature stratification was an important source of heat loss (25\%) and that it needs to be corrected using ventilation systems capable of mixing the inside air.

Feedes et al. (2003) compared two different air exchange rates and reported that the average maximum temperatures on day 20 of the rearing period of broilers were $30.5^{\circ} \mathrm{C}$ e $30.0^{\circ} \mathrm{C}$ for the treatments with high and low air exchange rates, respectively. According to those authors, broilers reared in environments with low air exchange rates consumed more water, which suggests that these birds were close to experiencing thermal stress. Lott (1991) found that broilers submitted to heat stress consume more water, trying to reduce their elevated body temperatures. Also, Howlider \& Rose (1989) found that broilers reared in environments with low air exchange rates increased their feed intake when mean environmental temperature was $21^{\circ} \mathrm{C}$.

These results emphasize the importance of adequate operation of minimum ventilation systems in poultry houses, since minimum ventilation operation, as well as system design, depend on specific climatic data where the facility is located (ASRHAE, 1997). Wheeler et al. (2000) also emphasized that, although the heat loss should be kept in a minimum rate inside an animal facility, minimum ventilation practices are required to maintain proper control of environmental variables, such as relative humidity and temperature, as well as to provide good air quality with satisfactory bird performance.

\section{CONCLUSIONS}

The positive pressure ventilation system (PP) provided less aversive temperature and relative humidity conditions, and promoted lower feed conversion during minimum ventilation operation. Ventilation systems did not significantly influence $\mathrm{CO}_{2}$ concentrations.

\section{REFERENCES}

Andonov K, Daskalov P, Martev K. A new approach to controlled natural ventilation of livestock buildings. Biosystems Engineering 2003;84:91100 .

ASHRAE. Fundamentals, 9.1. In: ASHRAE Handbook. Atlanta, Ga: American Society of Heating, Refrigerating and Air Conditioning Engineers; 1997

Barber EM, Dawson JR, Battams VA. Assessment of dustfall collectors used in livestock buildings. Journal of Agricultural Engineering Research 1991;50:157-162

Boni IJ, Konzen FA, Vizzotto MA. Manejo reprodutivo de perus. Revista Brasileira de Reprodução Animal, Belo Horizonte 2007;31(3):328-332.

Bucklin RA, Jacob JP, Mather FB, Leary JD, Nääs IA. Tunnel ventilation of broiler houses [FACTSHEET PS-46]. Gainesville: Institute of Food and Agricultural Sciences, University of Florida; 2009

Cordeau S, Barrington S. Heat balance for two commercial broiler barns with solar preheated ventilation air.. Biosystems Engineering 2010;107:232-241.

Feddes JJR, Emmanuel EJ, Zuidhof MJ, Korver DR. Ventilation rate, air circulation, and bird disturbance: Effects on the incidence of cellulitis and broiler performance. Journal of Applied Poultry Research 2003;2:328-334.

Frame DD, Buckner RE, Anderson GL. Causes and control of spontaneous cardiomyopathy or roundheart disease in Utah turkeys [bulletin AG506]. Logan: Utah State University; 1999. p.9.

Gates RS, Xin H, Casey KD, Liang Y, Wheeler EF. Method for measuring ammonia emissions from poultry houses. Journal Applied Poultry Research 2005 14:622-634.

Gerritzen M, Lambooij B, Reimert H, Stegeman A, Spruijt B. A note on behaviour of poultry exposed to increasing carbon dioxide concentrations. Applied Animal Behavior Science 2006; 108(1):179185.

Goovaerts P. Geostatistics for Natural Resources Evaluation. New York/ Oxford University Press; 1997.

Havenstein GB, Ferket PR, Grimes JL, Qureshi MA, Nestor, KA Comparison of the Performance of 1966- Versus 2003-Type Turkeys When Fed Representative 1966 and 2003 Turkey Diets: Growth Rate, Livability, and Feed Conversion. Poultry Science 2007 86(2) 232-240.

Howlider MAR, Rose SP. Rearing temperatures and meat yield of broilers. Brazilian Poultry Science 1989 30:61-67. 
Janni KN, Redig PT, Newman JA. Effects of dust and ammonia on turkeys.. Proceedings of the ASAE Paper No. 89-4022; 1989; St. Joseph, Michigan. United State of America.

Klooster CE, Roelofs PFMM, Gijsen PAM. Positioning air inlet and air outlet to reduce dust exposure in pig buildings. Proceedings of $4 \mathrm{tV}$ International Symposium on Livestock Environment; 1993; Conventry, England. p. 754-760

Lott BD. The effect of feed intake on body temperature and water consumption of male broilers during heat exposure. Poultry Science 1991 70:756-759

Menegali I, Tinôco IFF, Gates RS, Baêta FC, Carvalho CCS. Effect of two different minimum ventilation systems on the thermal comfort and productive performance of broiler chickens in winter conditions.: 8 thLivestock Environmenl; 2008; Foz do Iguaçu, Paraná. Brasil. p. 65.

Miragliotta MY. Avaliação das condições do environmente interno em dois galpões de produção comercial de frangos de corte, com ventilação e densidade populacional diferenciado. [Tese]. Campinas (SP): Universidade Estadual de Campinas; 2005.

Miragliotta, M.Y.; Nääs, I.A.; Manzione, R.L.; Nascimento, F.F. Spatial analysis of stress conditions inside broiler house under tunnel ventilation. Scientia Agricola 2006 63(5):426-432.

Mutaf S, Alkan S, Seber N. The effects of natural ventilation air exchange on psychrometric results in poultry houses in hot environment and design characteristics. In: Agricultural Engineering International: the CIGR Journal of Scientific Research and Development; 2004. p.1-11.

Nixey C, Grey TC. Recent advances in turkey science. London(UK): Butterworths; 1986.

Noll SL, Nagaraja KV, Halvorson DA, Janni KA. Air quality in Turkey Production. Minneapolis: University of Minnesota; 2003. p.8.

Ryan BF, Joiner BL, Ryan Jr TA. Minitab Handbook. .ed. Boston: PWS-KENT Publishing Company. 1985. p.376.

Seedorf J, Hartung J, Schröder M, Linkert KH, Pedersen S, Takai H, Johnsen JO, Metz JHM, Groot Koerkamp PWG, Uenk GH, Phillips VR, Holden MR, Sneath RW, Short JLL, White RP, Wathes CM. A Survey of Ventilation Rates in Livestock Buildings in Northern Europe. Journal of Agricultural Engineering Research 1998 70:39-47.

Senthilselvan A, Dosman JA, Kirychuk SP, Barber EM, Rhodes CS, Zhang $Y$, Hurst TS. Accelerated lung function decline in confinement swine building workers. CHEST 1997; 111(6):1733-1741.

Seo HI, Lee IB, Chang PW, Hwang HS, Hong SW, Lee SY. Study on Ventilation System of Naturally ventilated Broiler House by Aerodynamic approach [06401].: ASABE Meeting Presentation; 2006; Oregon., United State of America.

Van der Hel W, Verstergen MWA, Pijls L, Van Kampen M. Effect of two day temperature exposure of neonatal broiler chicks on growth performance and body composition during two weeks at normal conditions. Poultry Science 1992 71:2014-2021.

Wang X, Zhang Y, Riskowski GL. Dust spatial distribution in a typical swine building. In: International Symposium on "Dust Control for Animal Production Facilities"; 1999; Jatland. Denmark.

Wang $X$, Zhang Y. Development of a critical air flow venturi for air sampling. Journal Agricultural Engineering Research 1999 73:257-264.

Wathes CM, Phillips VR, Holden MR, Sneath RW, Short JL, White RPP, Hartung J, Seedorf J, Schröder M, Linkert KM, Pedersen S, Takai H, Johnsen JO, Groot Koerkamp PWG, Uenk GH, Metz JHM, Hinz T, Caspary $\mathrm{V}$, Linke $\mathrm{S}$. Emission of aerial pollutants in livestock buildings in Nothern Europe: Overview of a multinational project. Journal of Agricultural Engineering Research 1998; 70(1):3-9.

Weaver WD, Meijerhof R. The effect of different levels of relative humidity and air movement on litter conditions, ammonia levels growth, and carcass quality for broiler chickens. Poultry Science 1991 70:746-755.

Wheeler EF, Zajaczkowski JS, Weiss RWJ. Temperature stratification and fuel use during winter in three pennsylvania broiler houses. Journal Applied Poultry Research 2000 9:551-562.

Xin H, Chepete HJ, Shao J, Sell JL. Heat and moisture production and minimum ventilation requirements of tom turkeys during broodinggrowing period. Transactions of the ASAE 1998; 41(5):1489-1498.

Yahav S, Druyan S, Rusal M, Shinder D. Diurnally cycling temperature and ventilation affect young turkeys' performance and sensible heat loss. Institute of Animal Science. Journal of Thermal Biology 201136334 339.

Yahav S, Plavnik I, Rusal M, Hurwitz S. Response of turkeys to relative humidity at high environment temperature. British Poultry Science 1998 39:340-345.

Yaha, .; Shinde, D,; Ruza, M; Gilo, M; Piestu,Y. Controlling body temperature the opportunities forhighly productive domestic fowl. In: Cisnero, ..., Goin, .L, editors.,Body Temperature Control. Nova Science Publishers Inc; 2009; New York. Unided State of America. p.65-98.

Yalçin S, Testik A, Ozkan S, Settar P, Celen F, Cahaner A. Performance of Naked neck and normal broilers in hot, warm, and temperate climates. Poultry Science 1997 76(7):930-937.

Zhang Y, Wang X, Riskowski GL, Christianson LL. Quantifying ventilation effectiveness for air quality control. Transactions of the ASAE 2001 44:385-390.

Zuidhof M, Feddes JJR, Robinson FE. Effect of ventilation rate and stocking density on turkey health and performance. Journal Applied Poultry Research 1993 2:123-129. 